\title{
ГЛИКЕМИЧЕСКИЙ КОНТРОЛЬ У ДЕТЕЙ С САХАРНЫМ ДИАБЕТОМ, НАБЛЮДАЮЩИХСЯ В УСЛОВИЯХ ЕДИНОГО ЭНДОКРИНОЛОГИЧЕСКОГО ЦЕНТРА
}

\author{
Платонов В.В. ${ }^{1}$, Дубинина T.A. ${ }^{1}$, Патракеева Е.М. ${ }^{2}$
}

${ }^{1}$ СПбГБУЗ Детский городской многопрофильный клинический центр высоких медицинских технологий имени К.А.Раухфуса, Городской детский эндокринологический центр

${ }^{2}$ Первый Санкт-Петербургский Государственный Медицинский Университет имени И.П. Павлова

Достижение целевого уровня гликированного гемоглобина в настоящее время остается трудно достижимой целью во многих регионах, обеспечивающих комплексное наблюдение за детьми с сахарным диабетом 1 типа, вне зависимости от географического положения, а также лекарственного и технического обеспечения. Менее трети пациентов с сахарным диабетом 1 типа достигают целевых значений гликемического контроля, как по данным ISPAD, так и ADA. По последним данным средний уровень гликированного гемоглобина в детском возрасте достоверно повышается к пубертатному возрасту, достигая максимальных средних значений к середине пубертата, с последующим постепенным снижением ко взрослому возрасту. Наличие и доступность современных технических средств введения инсулина и гликемического контроля не может в настоящее время обеспечить должного снижения среднего уровня гликированного гемоглобина в педиатрической популяции, демонстрируя тем самым так называемый «парадокс технологий». С другой стороны, обеспечение комплексного персонализированного подхода к наблюдению за ребенком с сахарным диабетом в условиях единого диабетического центра может оказывать положительное влияние на достижение удовлетворительной компенсации сахарного диабета.

Цель исследования: оценить компенсацию детей с сахарным диабетом 1 типа, наблюдающихся исключительно в условиях Городского детского эндокринологического центра по сравнению с детьми с сахарным диабетом 1 типа, наблюдающимися одновременно в нескольких лечебных учреждениях.

Материалы исследования. В Городском детском эндокринологическом центре ведется общегородской регистр регистр детей с сахарным диабетом 1 типа - 2120 детей от 0 до 18 лет. Эти дети получают медицинскую помощь как в поликлинических отделениях по месту жительства, так и в условиях Центра. 370 из них наблюдаются исключительно в условиях Центра.

По данным общего регистра средний уровень гликированного гемоглобина у детей в СанктПетербурге составляет $7.96 \pm 1,92 \%$.

Были оценены данные уровня гликированного гемоглобина у 370 пациентов с сахарным диабетом, наблюдающихся в условиях эндокринологического центра с целью оценки эффективности персонализированного наблюдения.

Характеристика группы исследования: 370 пациентов с сахарным диабетом 1 типа от 0 до 18 лет (средний возраст 11,2 $\pm 4,2$ года), из них мальчиков - 170 человек $(45,9 \%)$, девочек 200 человек $(54,1 \%)$. Достоверной разницы в возрасте обследованных детей не было средний возраст мальчиков $11,1 \pm 4,5$ лет, девочек $11,2 \pm 4,1$ года. Разница в объемах медицинской помощи, лекарственном и техническом обеспечении не было.

Результаты. Отмечена выраженная достоверная статистическая разница в уровне гликированного гемоглобина обследованных детей, так средний уровень гликированного гемоглобина у обследованных детей составил $7,17 \pm 1,43 \%$, у мальчиков - $6,99 \pm 1,13 \%$, у девочек $-7,33 \pm 1,63 \%(p=0,01)$

Выводы. Таким образом можно сделать заключение о том, что обеспечение персонализированного наблюдения за детьми с сахарным диабетом 1 типа в условиях единого эндокринологического центра может сопровождаться достоверным улучшением гликемического контроля. 